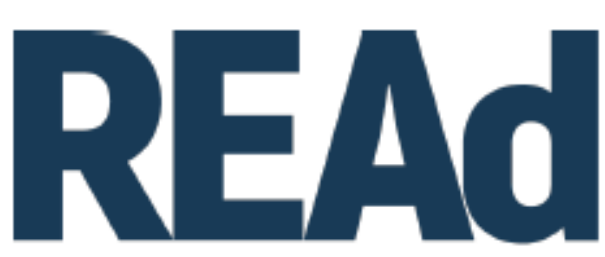

Revista Eletrônica de Administração

\title{
NOVO NEOLIBERALISMO ACADÊMICO E O ENSINO SUPERIOR NO BRASIL ${ }^{1}$
}

\author{
Camila Furlan da Costa ${ }^{2}$ \\ Sueli Maria Goulart Silva ${ }^{3}$
}

$\underline{\text { http://dx.doi.org/10.1590/1413-2311.251.89569 }}$

\section{RESUMO}

A implementação de programas e políticas nas universidades públicas brasileiras, nos últimos 15 anos criaram novos mecanismos de integrá-las aos circuitos de reprodução do capital, sem modificar sua natureza jurídica. Em um contexto de aceleração tecnológica e aprofundamento da crise do capital, criaram-se novas formas de apropriação capitalista do conhecimento produzido pelas universidades públicas brasileiras, em todas as suas atividades. Este artigo busca contribuir para a caracterização do novo neoliberalismo acadêmico a partir da análise da articulação entre as políticas de ampliação do acesso e de incentivo à inovação nas universidades públicas brasileiras. O Novo Neoliberalismo acadêmico é um conceito que descreve a exacerbação das características historicamente registradas na mercantilização capitalista no ensino superior. No Brasil, as políticas neoliberais para o ensino superior foram se transformando, adquirindo novas características em função das mudanças nas recomendações dos organismos internacionais. Caracterizamos, assim, o novo neoliberalismo acadêmico como um conjunto de políticas e programas que criam políticas ditas inclusivas;

\footnotetext{
${ }^{1}$ Recebido em 13/1/2019, aceito em 8/10/2019

2 Universidade Federal do Pampa - Campus Santana do Livramento e Programa de Pós-Graduação em Administração; Santana do Livramento - RS (Brasil); https://orcid.org/0000-0002-7189-8394; camilacosta@unipampa.edu.br

${ }^{3}$ Universidade Federal do Rio Grande do Sul - professora aposentada Escola de Administração e PPGA; Porto Alegre - RS (Brasil); https://orcid.org/0000-0002-4654-6303; sueli.goulart@ufrgs.br
} 
flexibilizam a formação por meio da oferta de novas modalidades de cursos; modificam o financiamento; estabelecem o empreendedorismo como cultura a ser disseminada pela universidade; difundem o gerencialismo; e precarizam as relações de trabalho nas universidades públicas.

Palavras-chave: Neoliberalismo Acadêmico. Ensino Superior Brasileiro. Política de Ampliação do Acesso. Política de Ciência Tecnologia e Inovação.

\title{
NEW ACADEMIC NEOLIBERALISM AND HIGHER EDUCATION IN BRAZIL
}

\begin{abstract}
The implementation of programs and policies in Brazilian public universities in the last 15 years created new mechanisms to integrate them into the circuits of reproduction of capital, without changing their legal nature. In a context of technological acceleration and intensification of the capital crisis, new forms of capitalist appropriation of the knowledge produced by Brazilian public universities were created in all their activities. This article seeks to contribute to the characterization of new academic neoliberalism by analyzing the articulation between the access expansion policies for students and the fostering innovation policies in Brazilian public universities. New Academic neoliberalism is a concept that describes the exacerbation of historically recorded characteristics of capitalist commodification in higher education. In Brazil, neoliberal policies for higher education were transformed, acquiring new characteristics due to the changes in the recommendations of the international organisms. Thus, we characterize new academic neoliberalism as a set of policies and programs that create so-called inclusive policies; make training flexible by offering new courses; modify funding; establish entrepreneurship as a culture to be disseminated by the university; spread the managerialism; and precarious labor relations in public universities.
\end{abstract}

Keywords: Academic Neoliberalism. Brazilian Higher education. Access Expansion Policies. Science, Technology and Innovation Policy.

\section{NUEVO NEOLIBERALISMO ACADÉMICO Y LA ENSEÑANZA SUPERIOR EN BRASIL}




\section{RESUMEN}

La implementación de programas y políticas en las universidades públicas brasileñas, en los últimos 15 años, han creado nuevos mecanismos para integrarlos en los circuitos de reproducción del capital, sin cambiar su naturaleza jurídica. En un contexto de aceleración tecnológica y profundización de la crisis del capital, se crearon nuevas formas de apropiación capitalista del conocimiento producido por las universidades públicas brasileñas, en todas sus actividades. Este busca contribuir a la caracterización del nuevo neoliberalismo académico a partir del análisis de la articulación entre las políticas de ampliación del acceso y de incentivo a la innovación en las universidades públicas brasileñas. El nuevo neoliberalismo académico es un concepto que describe la exacerbación de las características históricamente registradas en la mercantilización capitalista en la enseñanza superior. En Brasil, las políticas neoliberales para la enseñanza superior se fueron transformando, adquiriendo nuevas características en función de los cambios en las recomendaciones de los organismos internacionales. Caracterizamos, así, el nuevo neoliberalismo académico como un conjunto de políticas y programas que crean políticas dichas inclusivas; flexibilizan la formación a través de la oferta de nuevas modalidades de cursos; modifican la financiación; establecen el emprendedorismo como cultura a ser diseminada por la universidad; difunden el gerencialismo; y precarizan las relaciones de trabajo en las universidades públicas.

Palabras clave: Neoliberalismo académico. Enseñanza superior brasileño. Política de Ampliación del acceso. Política de Ciencia Tecnología e Innovación.

\section{INTRODUÇÃO}

As mudanças no ensino superior brasileiro apresentaram grandes avanços nos governos de Luís Inácio Lula da Silva (2003-2010) e de Dilma Roussef (2011-2016) quando se olham os dados de acesso. Houve uma expansão significativa do número de matrículas, com um crescimento acumulado de aproximadamente 107\% entre os anos de 2003 e 2016 (BRASIL, 2018). Estes governos implementaram um conjunto de políticas públicas com vistas a superar déficits históricos em diversas áreas como habitação, saúde e educação. Os governos assumiram 
a agenda neodesenvolvimentista, carregada da ideia de reversão das políticas neoliberais vigentes no país desde os anos 1980.

No âmbito do ensino superior, os governos Lula e Dilma estruturam três programas voltados para ampliação do acesso ao ensino superior, um deles direcionado para as universidades públicas, o Programa de Apoio a Planos de Reestruturação e Expansão das Universidades Federais (Reuni) ${ }^{4}$; e dois focados na ampliação do acesso em instituições privadas, o Fundo de Financiamento Estudantil (FIES) ${ }^{5}$ e do Programa Universidade para Todos (PROUNI) ${ }^{6}$. Na pesquisa e extensão, as instituições de ensino superior, principalmente as universidades públicas, assumiram a função da geração de inovação, incentivadas pela Política Nacional de Ciência, Tecnologia e Inovação. A estruturação dessas políticas ampliou o investimento do governo federal no ensino superior e em pesquisa aplicada.

Esses novos projetos podem, aparentemente, representar que houve superação do projeto neoliberal para o ensino superior. Entretanto, argumentamos que a estruturação de novos projetos para o ensino superior brasileiro nos Governos Lula e Dilma decorrem da renovação do próprio projeto neoliberal. Essa renovação foi necessária para atenuar os efeitos do neoliberalismo ortodoxo que envolveram o aumento da pobreza nos países periféricos. Assim, a partir dos anos 2000, os organismos internacionais modificaram suas recomendações, incluindo a educação como um investimento necessário nestes países.

Do ponto de vista empírico, sustentaremos nosso argumento descrevendo tais políticas e programas; do ponto de vista analítico, buscaremos compreender as mudanças no âmbito do próprio neoliberalismo, com base fundamentalmente em Harvey (2011; 2014a; 2014b) e em Puello-Socarrás (2008a; 2008b; 2013; 2015). Deste último exploraremos, particularmente o construto "novo neoliberalismo acadêmico", cuja abordagem original apresentou, até onde pudemos averiguar, em um único texto. Nele, o autor aponta, brevemente, os casos de reformas no Chile e na Colômbia, destacando as novidades sofisticadas de um "neoliberalismo académico en curso" (PUELLO-SOCARRÁS, 2011, p. 22), especialmente nos modos sofisticados de financiamento do ensino superior nas universidades. A brevidade com que foi

\footnotetext{
4 O REUNI foi instituído pelo Decreto $\mathrm{n}^{\circ}$ 6096, de 24 de abril de 2007, com o intuito de "criar condições para a ampliação do acesso e permanência na educação superior, no nível de graduação, pelo melhor aproveitamento da estrutura física e de recursos humanos existentes nas universidades federais" (BRASIL, 2007).

5 O Fies, regulamentado pela Lei 10.260/2001, consiste em programa do Ministério da Educação destinado a financiar a graduação na educação superior de estudantes matriculados em cursos superiores não gratuitos.

6 O PROUNI foi criado pela Lei n ${ }^{\circ} 11.096 / 2005$ para a concessão de bolsas de estudo integrais e parciais de 50\% em instituições privadas de educação superior, em cursos de graduação e sequenciais de formação específica, a estudantes brasileiros sem diploma de nível superior (BRASIL, 2005), a partir de renúncia fiscal concedida a universidades privadas.
}

(c) (1) 9 REAd | Porto Alegre - Vol. 25 - N. ${ }^{\circ} 3$ - Setembro / Dezembro 2019 - p. 6 - 35 
abordado o tema naquele artigo (PUELLO-SOCARRÁS, 2011), somado à profundidade da análise que faz o autor, em várias outras produções, sobre as metamorfoses do neoliberalismo como projeto de classe, nos instigou a analisar a realidade brasileira do ensino superior nos últimos 15 anos. Por um lado, com o objetivo de sustentar nosso argumento e, por outro, de tensionar o construto frente ao real na expectativa de contribuir para continuar a disputa de ideias e de práticas, reposicionando-as para o campo da economia política da educação ${ }^{7}$.

Este estudo utilizou o materialismo histórico-dialético como perspectiva teóricametodológica. As mudanças nas universidades públicas foram escolhidas como objeto de análise. A universidade pública não foi considerada uma estrutura estática, mas como síntese de múltiplas relações dotadas de contradições, e pertencentes a uma totalidade. A operacionalização do estudo aconteceu por meio da análise de documentos como os relatórios oficiais do governo brasileiro e de organismos internacionais. A coleta de dados envolveu a realização de entrevistas semiestruturadas com gestores e especialistas de notório saber vinculados a uma universidade federal e ao Ministério da Educação, além de coleta e organização de dados secundários obtidos nos relatórios oficiais.

Para fins de organização da argumentação, o texto está estruturado na seguinte forma: na seção seguinte, apresentamos as elaborações centrais sobre o neoliberalismo e suas metamorfoses, particularmente as de Harvey e de Puello-Socarrás. Advertimos que não abraçamos a precedência da teoria sobre a realidade, mas consideramos a necessidade de apresentar os conceitos com o quais iremos trabalhar para melhor compreensão do que será discutido, conjuntamente com a descrição e análise dos programas e políticas voltados para a ampliação do acesso e incentivo à inovação no ensino superior público brasileiro, na seção seguinte. Nas conclusões, discutimos as possibilidades do construto novo neoliberalismo acadêmico para entendimento de nossa realidade e para futuros estudos.

\section{O NEOLIBERALISMO E SUAS METAMORFOSES}

Historicamente, como teoria de práticas político-econômicas, o neoliberalismo emerge da desordem do capitalismo global pós-Segunda Guerra (HARVEY, 2011), sob a liderança de

\footnotetext{
7 Com isto queremos dizer que compreendemos o tema da educação e, especificamente sobre o ensino superior no Brasil, imbricado na trama da vida social, marcado por interesses materiais de grupos e classes sociais. Entretanto, neste artigo, não exploraremos as categorias da Economia Política para a análise do objeto, desafio que poderá ser enfrentado em outros textos.
} 
Friedrich von Hayek e da Mont Pelerin Society. O neoliberalismo foi inserido na agenda dos países capitalistas em meados dos anos 1970 do século passado, como uma resposta aos problemas estruturais do capitalismo emergentes naquele período. Harvey (2011) refere-se aquele período como o da primeira crise em escala global do capitalismo no pós-Segunda Guerra. Aquele momento histórico também foi acompanhado pela elevação dos preços do barril de petróleo, pela quebra financeira do mercado imobiliário global, que arrasou vários bancos e afetou as finanças do Estado de forma drástica. Caberia então ao Estado não mais investir, mas construir um arcabouço institucional para garantir as liberdades individuais, bem como utilizarse do monopólio dos meios de violência para preservar essas liberdades. A privatização dos ativos é uma das bandeiras dos neoliberais, pois é uma das melhores maneiras de proteger as pessoas da "tragédia do bem comum" e alavancar o desenvolvimento econômico e o bemhumano (HARVEY, 2014a).

Para Harvey (2014a) a teoria geral do Estado neoliberal apresenta algumas tensões e contradições. A primeira diz respeito à interpretação dos monopólios. A competição tende ao monopólio, uma vez que as empresas mais fortes expulsam as mais fracas do mercado. Para os teóricos neoliberais, este não é um problema, desde que não haja barreiras para a entrada de novos competidores. A segunda versa sobre o fracasso do mercado, uma vez que as empresas e os indivíduos evadem de pagar todos os custos que lhe incumbem, como no caso da poluição gerada pela atividade econômica. Neste caso alguns neoliberais defendem a intervenção e a regulação estatal, outros defendem a inação, dado que as consequências da intervenção estatal seriam mais danosas para os mercados (HARVEY, 2014a). A terceira contradição refere-se ao pressuposto de que todos os agentes do mercado têm as mesmas informações. Para Harvey (2014a) é raro que isso seja alcançado de fato na prática. Assim, agentes mais bem informados e mais fortes tendem a obter maiores ganhos, gerando concentração de riqueza. Um exemplo dessa concentração está no estabelecimento de direitos de propriedade intelectual (patentes). Aquele agente que detém os diretos de patente usa seu poder de monopólio sobre determinado processo ou produto para estabelecer o monopólio de preços e, somente realiza a transferência de tecnologia através do pagamento de altos preços (HARVEY, 2014a).

A competição, como pressuposto, faz com que haja uma busca intermitente por novos produtos, novos métodos e novas formas organizacionais, o que Harvey (2014a) caracterizou como teoria neoliberal da mudança tecnológica, entre cujos efeitos está a crença de que há remédio tecnológico para todos os problemas. Por isso, o autor vê uma relação direta entre 
dinamismo tecnológico, instabilidade, dissolução de solidariedades, degradação ambiental, desindustrialização e a tendência geral de formação de crises no capitalismo.

É importante destacar que a integração dos países latinos americanos ao neoliberalismo apresenta suas particularidades. Em função da crise estrutural do capitalismo da década de 1970, a economia americana entrou em recessão e uma das consequências foi o endividamento das famílias estadunidenses, com hipotecas, por exemplo, que comprometeram grande parte de sua renda. Os bancos estavam ávidos por novas oportunidades de investimentos uma vez que sua possibilidade de rentabilidade dentro dos EUA estava estagnada. Assim, passaram a exportar capital e cultivar novos mercados ao redor do mundo, realizando empréstimos maciços para países em desenvolvimento como o México, o Brasil e o Chile.

Na década de 1980, emergiu a crise da dívida dos países em desenvolvimento, que passaram por dificuldades para pagar seus empréstimos quando as taxas de juros subiram ${ }^{8}$ (HARVEY, 2011). Os países tiveram que recorrer ao Fundo Monetário Internacional (FMI) que por sua vez determinou uma série de programas de ajuste estrutural. Estes programas tinham a finalidade de garantir que os bancos recebessem o dinheiro que foi emprestado. A recomendação de ajuste estrutural desencadeou a implementação de políticas neoliberais nos países da América Latina.

O neoliberalismo, assim, teve como sua primeira experiência prática concreta as reformas de Estado realizadas no Chile pelo governo ditatorial de Augusto Pinochet (1973). O marco para a implementação de políticas neoliberais, em governos democráticos na América Latina, foi dado pelo conhecido Consenso de Washington (1989).

Essa implementação não foi um ato exclusivo da América Latina, já que a partir dos anos 1980, uma vasta onda de privatizações "varreu" o mundo na tentativa desesperada de encontrar mais locais para colocar o excedente de capital, sob "a alegação dogmática de que empresas estatais são ineficientes e desengajadas por definição, e a única maneira de melhorar seu desempenho e passá-las ao setor privado" (HARVEY, 2011, p. 32). Para Harvey (2011) independentemente de serem ineficientes ou não, as empresas estatais tiveram de ser abertas ao capital privado, que devido à baixa rentabilidade da indústria a partir dos anos 1970, não tinham para onde ir. Serviços de utilidade pública como água, eletricidade, telecomunicações,

\footnotetext{
8 O período de 1979 a 1982 foi marcado nos Estados Unidos pela alta da inflação e elevação das taxas de juros que geraram recessão no país, fazendo os índices de desemprego ficarem em torno de $10 \%$. Esta condição interna desencadeou entre 1982 e 1990 a crise da dívida dos países em desenvolvimento (México, Brasil, Chile, Argentina, Polônia etc.), ocasionada pela elevação das taxas de juros na economia americana (HARVEY, 2011).
}

(c) (1) $\Theta$ REAd | Porto Alegre - Vol. 25 - N. ${ }^{\circ} 3$ - Setembro / Dezembro 2019 - p. 6 - 35 
transporte, habitação, educação e saúde tiveram que passar para a iniciativa privada e para economia de mercado.

As condições concretas mostraram que o neoliberalismo foi incapaz de promover o crescimento econômico, com estabilidade monetária e com melhoria na distribuição da renda nos países periféricos (PINTO; BALANCO, 2013). Estes resultados e as críticas às políticas formatadas pelo Consenso de Washington geraram um relativo enfraquecimento da capacidade de intervenção direta dos EUA na América Latina, principalmente a partir da ascensão de governos de corte popular de 2002 em diante. Concomitantemente, um novo eixo geoeconômico se desencadeou com a ampliação das relações comerciais entre os países da América Latina e a China nos anos iniciais do século XXI, possibilitando a retomada de políticas do tipo desenvolvimentistas. A dinâmica externa alterada a partir da ascensão chinesa gerou, para os países produtores de commodities, como o Brasil, a possibilidade de investimentos públicos em infraestrutura e em maiores gastos em políticas sociais.

Pinto e Balanco (2013, p. 29) viram, nesta dinâmica, a construção de:

[...] modelos híbridos que combinam, por um lado, elementos do modelo neoliberal anterior e, por outro, elementos novos associados ao fortalecimento do mercado interno que tem produzido resultados positivos no que tange à melhora da renda dessas populações e, principalmente, para a redução da pobreza extrema regional.

Para Puello-Socorrás (2013), entretanto, não seria um modelo híbrido, mas o próprio neoliberalismo que estaria se adaptando para a sua reconstituição e consolidação como projeto hegemônico. Outra importante observação apontada por Pinto e Balanco (2013) é que as mudanças não ocorreram em países como o Brasil a partir de crises político-econômicas estruturais, ou seja, através de alterações nos blocos de poder. Por isso, apesar dos avanços observados, principalmente na ampliação das políticas públicas de redução de pobreza extrema, a atuação do Estado permaneceu fortemente atrelada aos segmentos dominantes financeiros externos e internos hegemônicos desde a década de 1990.

Em vista do estudo desses processos, Puello-Socarrás (2013) defende que o neoliberalismo tem se transformado para manter-se como corrente ideológica hegemônica, pois ao gerar uma série de crises econômicas, precisa se reformular.

Puello-Socarrás (2008a; 2008b; 2013) distingue, então, dois tipos de neoliberalismo: velho (ortodoxo) baseado na Escola Anglo-Americana e o novo (heterodoxo), baseado na Escola Austríaca. O novo neoliberalismo seria fruto de críticas ao neoliberalismo ortodoxo. Assim, essas novas correntes buscaram a sua reconstituição e permanência. O velho 
neoliberalismo tem uma conexão forte com as teorias neoclássicas, vinculadas a Escola angloamericana, na qual há uma desregulamentação e liberalização total dos mercados (PUELLOSOCORRÁS, 2013). Já o novo neoliberalismo está filiado à Escola Austríaca, na qual o Estado tem como papel a regulamentação. O Quadro 1 sistematiza as diferenças entre os dois tipos de neoliberalismos.

\begin{tabular}{|c|c|c|}
\hline Dimensões & "Velho" Neoliberalismo & "Novo" Neoliberalismo \\
\hline $\begin{array}{c}\text { Estado } \\
\text { (Presença enquanto aparattus) }\end{array}$ & $\begin{array}{c}\text { Desregulamentação } \\
\text { Intervenção estatal ou } \\
\text { Planejamento Estatal impossível } \\
\text { Estado de Inação }\end{array}$ & $\begin{array}{c}\text { Regulamentação } \\
\text { A intervençãão estatal não está } \\
\text { permitida a não ser na regulação } \\
\text { (ação oportunista e momentânea) } \\
\text { Planejamento centralizado } \\
\text { impossível } \\
\text { Estado da reação }\end{array}$ \\
\hline $\begin{array}{c}\text { Mercado } \\
\text { (Desempenho) }\end{array}$ & $\begin{array}{c}\text { Liberalização com extrema } \\
\text { liberdade dos mercados. O } \\
\text { mercado como produto das falhas } \\
\text { do Estado/Governo }\end{array}$ & $\begin{array}{c}\text { Liberalização com liberdade do } \\
\text { mercado. Regulações do Estado } \\
\text { em função do mercado (suas } \\
\text { falhas) }\end{array}$ \\
\hline $\begin{array}{c}\text { Sociedade } \\
\text { (Saldos sociais e extra } \\
\text { econômicos) }\end{array}$ & $\begin{array}{l}\text { Espontâneos ou autorregulados } \\
\text { pelo mercado }\end{array}$ & $\begin{array}{l}\text { Induzidos por quase mercados } \\
\text { regulados pelo Estado }\end{array}$ \\
\hline $\begin{array}{c}\text { Raízes Ideológicas } \\
\text { (pensamento neoclássico) }\end{array}$ & $\begin{array}{c}\text { Ortodoxa } \\
\text { Escolas anglo-americanas como } \\
\text { referência chave } \\
\text { Fundamentos do mercado: } \\
\text { perspectivas ultraliberais } \\
\text { leseferiana (laisseiz-faire)... }\end{array}$ & $\begin{array}{c}\text { Heterodoxa } \\
\text { Austríacos e alemães } \\
\text { Economia Social de Mercado } \\
\text { (ESM) como referências chaves. } \\
\text { O mercado é fundamental: } \\
\text { perspectiva proneoliberal anti- } \\
\text { laisseiz-faire. }\end{array}$ \\
\hline
\end{tabular}

Fonte: Tradução Livre de Pueblo-Socorras (2013, p. 36).

Além disso, o velho neoliberalismo é deliberadamente anti-estadista, enquanto que o novo permite a presença do Estado, ainda que anti-intervencionista. $\mathrm{O}$ novo neoliberalismo busca sintetizar modos de organização social consideradas dicotômicas e irreconciliáveis (Estado e Mercado), em uma narrativa compatível e convergente, de onde podem derivar politicas market-friendly (PUELLO-SOCORRÁS, 2008b). Essa conciliação, para PuelloSocarrás (2008b), aproxima-se da correlativa política Latino-americana da chamada "Terceira Via", que tem um papel específico dentro das novas configurações do novo neoliberalismo.

É importante salientar que diversos autores caracterizam a terceira via como uma alternativa ao neoliberalismo, enquanto que Puello-Socarrás (2008a; 2008b) coloca esta abordagem como uma correlativa política do novo neoliberalismo. A terceira via influencia de forma determinante as reformas de Estado no novo neoliberalismo, pois: 
[...] proporciona um domínio que desvincula o "público" do "estatal" em uma espécie de "espaço público-privado", ou como tem se denominado um "espaço público não estatal" que resulta aberta e fundamentalmente mercantil (...) e lócus natural do empreendedorismo (PUELLO-SOCARRÁS, 2008b, p. 23, tradução nossa).

Para Puello-Socarrás (2008b, p. 33) “o referencial de empreendedorismo pretende criar uma classe imparcial (neutralizada) que desconsidera as relações conflitivas entre trabalho (e trabalhadores) e capital (capitalista) como opção mediadora - "terceira via", "terceiro lugar", "terceiro discurso" - do capitalismo real. Também tem guiado de forma contundente o arcabouço teórico que visa adaptar a administração pública para a nova era neoliberal. Essa adaptação ocorre através da utilização de ferramentas gerenciais provenientes da administração privada e tem como objetivo construir uma governança neoliberal (empreendedora), tornando o mercado como o paradigma exclusivo da produção social (PUELLO-SOCARRÁS, 2008a).

Assim, não podemos reduzir o neoliberalismo apenas como um conjunto de políticas econômicas (ou sociais), representado pelas recomendações do Consenso de Washington, mas sim como um projeto político mais amplo (de classe) e transnacional no capitalismo tardio (PUELLO-SOCARRÁS, 2008a, 2013) que tem modificado suas recomendações e avançado para diversas áreas como o ensino superior.

Na América Latina, a renovação do projeto conforme Puello-Socarrás (2013) teve origem nos movimentos anti-neoliberais. No Brasil, essa renovação possui relação direta com a emergência de modelo econômico regional denominado de novo desenvolvimentismo adotado pelos Governo Lula e Dilma. Esse modelo critica os efeitos do neoliberalismo ortodoxo e suas externalidades para países em desenvolvimento, e defende o resgate da macroeconomia keynesiana e da teoria econômica do desenvolvimento como estratégia de crescimento para países periféricos como o Brasil (BRESSER-PEREIRA, 2006), e têm como proposições:

[...] maior abertura da conta comercial do País, de forma negociada e com reciprocidades; novo papel do Estado, com destaque para o planejamento estratégico; estabilidade macroeconômica, incluindo estabilidade de preços, equilíbrio do balanço de pagamentos e câmbio apreciado; recusa da estratégia de crescimento com poupança externa e financiamento do desenvolvimento com recursos próprios (FAÉ; GOULART; ABDALA, 2016, p. 12).

No modelo novo desenvolvimentista, o Estado, para facilitar as transações mercantis, assume um papel de planejador e regulador do mercado, sendo que a melhora da condição de vida está atrelada ao desempenho das políticas econômicas (FAÉ; GOULART; ABDALA, 2016). Essas características aproximam o modelo ao novo neoliberalismo. O novo desenvolvimentismo consiste em uma perspectiva que se diferencia do nacional 
desenvolvimentismo, sendo que se caracteriza como a renovação do neoliberalismo, no qual elementos heterodoxos são agregados a seu receituário em um processo de adaptação (FAÉ; GOULART; ABDALA, 2016; PUELO-SOCARRÁS, 2013). Esta vinculação tem como elemento central o crescimento econômico, ou seja, esta é a justificativa para oferta de melhores condições de vida à população, uma vez que políticas macroeconômicas restritivas são articuladas com políticas públicas sociais (FAÉ; GOULART; ABDALA, 2016, p. 12), como a educação.

\section{A RENOVAÇÃO DO PROJETO NEOLIBERAL PARA O ENSINO SUPERIOR}

As críticas às recomendações do Consenso de Washington (1989) que, em função de sua orientação economicista e dos resultados de sua implementação geraram aumento da miséria e da pobreza em países periféricos, fizeram com que os organismos internacionais, como o Banco Interamericano de Desenvolvimento (BID) e o Banco Mundial (BM), revisassem suas orientações, incluindo novas temáticas, como o fortalecimento da educação (MISOCZKY; ABDALA; DAMBORIARENA, 2017).

O documento Más allá del Consenso de Washington: la hora de la reforma de 1998 do BM sugeriu, então, que a educação pública dos países da América Latina precisava melhorar sua qualidade. Para isso, recomendava a realização de uma segunda geração de reformas, que estaria mais focada na avaliação, com o objetivo de garantir um mínimo de qualidade para este setor (WORLD BANK, 1998). A educação foi deixada de lado nas recomendações do Consenso de Washington e precisava ser incluída, assim como a temática do desenvolvimento tecnológico.

A renovação do projeto neoliberal veio por meio de modificações na orientação das reformas nos países periféricos, incluindo, o ensino superior. A mudança no discurso para educação aconteceu na publicação do Documento estratégico del Banco Mundial: La educación en América Latina y el Caribe pelo BM em 1999. Neste documento, foi destacada a importância da educação como estratégia de erradicação da pobreza e de promoção do crescimento econômico, definindo como principal objetivo do BM para a América Latina e o Caribe aumentar o capital humano da região, particularmente dos mais pobres (WORLD BANK, 1999). Entre as estratégias recomendadas pelo BM, estava a diversificação e a reforma do ensino superior para melhorar a qualidade e a eficiência, melhorar o acesso da população 
com renda mais baixa e fortalecer o papel integral do setor privado no financiamento e na oferta de educação.

A política de inclusão proposta para o ensino superior foi uma das estratégias de renovação adotadas pelo neoliberalismo. Para Puello-Socarrás (2013), como o neoliberalismo produz e reproduz desigualdades sociais por meio da exploração econômica, ele precisa encontrar formas de evitar sua própria extinção. Assim, a inclusão social é uma fórmula que o próprio neoliberalismo encontrou para evitar extrapolar seus próprios limites, sem arriscar sua existência. É também uma tentativa de combater os movimentos contrários ao avanço do neoliberalismo, como os de resistência ao aprofundamento da mercantilização da educação pública realizado por movimentos populares, especialmente, em países da América Latina (PUELLO-SOCARRÁS, 2013).

$\mathrm{O}$ alívio da pobreza, na visão do $\mathrm{BM}$, deveria ser realizado por meio de políticas focalizadas e compensatórias, que envolvessem o aumento da capacidade de consumo, por meio de programas de complementação de renda; de oportunidades econômicas, da ampliação do capital humano; e da prestação de serviços sociais mínimos, como saúde e educação (GREGÓRIO, 2012). Segundo Lima (2011), a redução da pobreza, proposto no documento, tinha como objetivo garantir segurança ao capital, ao assegurar a formação de força de trabalho para suprir as novas demandas, principalmente aquelas oriundas do avanço tecnológico. $\mathrm{Ou}$ seja, a política proposta pelo BM naquele documento continua concebendo a educação como preparação da força de trabalho para o mercado e de dominação ideológica através da difusão da visão burguesa do mundo (LIMA, 2011).

Além da inclusão, o documento do BM publicado em 1999 recomendava, especificamente para o ensino superior as seguintes diretrizes: a) uso da tecnologia, por meio de programas de aprendizagem a distância, como uma forma de ampliar o acesso, melhorar a equidade e a eficácia, com custos mais baixos; b) criação de uma variedade mais ampla de instituições e cursos de ensino superior; c) fortalecimento do papel do setor privado, em função das limitações de financiamento estatal; d) melhoria da qualidade do ensino público e privado, por meio da flexibilização e modernização dos currículos, capacitação de docentes e a criação de modelos de avaliação; e) fortalecimento da pós-graduação na região. Para Gregório (2012, p. 12) há, nessas recomendações, um direcionamento do BM para mercantilização e a padronização do conhecimento, a fim de transformá-lo em produto negociável em qualquer parte do mundo, abrindo novos mercados para os investidores internacionais interessados em se apropriar dos lucros gerados por mais esta frente capitalista. 
A proposta de inclusão no ensino superior veio acompanhada por uma série de recomendações que visavam modificar as formas de oferta do ensino superior. Visando promover a flexibilização dos tipos de instituições, em 2000, o BM publicou o documento $L a$ educación en los países en desarrollo: peligros y promesas em parceria com a UNESCO. O documento propôs a composição de um modelo híbrido de ensino superior, composto por universidades, voltadas para a excelência em pesquisa e consideradas o topo da pirâmide educacional e as instituições de ensino superior não universitárias direcionadas para as necessidades do mundo do trabalho, ou seja, para a formação de profissionais com as competências requeridas pelo mercado. Essa flexibilização criou as condições essenciais para o crescimento da oferta do ensino superior por instituições privadas. Assim, a flexibilização é importante para a ampliação do acesso por meio de redução dos custos, fazendo com que seja possível impulsionar o mercado de ensino superior, sem o comprometimento dos orçamentos públicos com este nível de formação.

O documento recomendou, ainda, a interação entre universidade e indústria, já que para o BM, a universidade deve realizar pesquisa especialmente aplicada. As interações com o setor produtivo poderiam ser uma nova fonte de financiamento para as universidades, o que desoneraria o Estado do seu papel de financiador (BORGES, 2010). A partir dessas recomendações "a educação superior assume a responsabilidade de formação de competências necessárias ao mercado de trabalho e de produzir conhecimento e socializá-lo" (BORGES, 2010, p. 371).

Em 2003, o BM lançou o documento Construir Sociedades de Conocimiento: Nuevos Desafíos para la Educación Terciaria fazendo recomendações específicas para o ensino superior para países em desenvolvimento. As principais recomendações foram: a) desenvolvimento e aplicação do conhecimento, como necessário para o progresso social e economico, ou seja, as universidades devem desenvolver pesquisa aplicada; b) o direcionamento da formação no nível superior para criação, divulgação e aplicação eficaz do conhecimento, por meio da formação técnica e profissional; c) a responsabilização do Estado na criação de condições favoráveis para incentivar as instituições de ensino superior a serem mais inovadoras para responder melhor às necessidades de uma economia do conhecimento globalmente competitivo (WORLD BANK, 2003). Para Lima (2011, p. 87) "este documento operou um importante deslocamento da concepção de educação superior para educação terciária", tornando o ensino superior um fator primário da produção na economia mundial. Pra 
Gregório (2012), as recomendações do BM estão baseadas no pressuposto de que o aumento da produtividade é obtido por meio do fortalecimento das habilidades dos trabalhadores.

Percebe-se, com base nos documentos do BM apresentados, uma mudança no projeto neoliberal para o ensino superior. No velho neoliberalismo acadêmico, as orientações indicavam que o ensino superior tinha custos elevados para ser mantido pelo Estado em países periféricos, que deveriam investir, prioritariamente, no ensino básico. No novo neoliberalismo, as recomendações sugerem a ampliação do ensino superior, estruturação de políticas inclusivas, bem como a realização de parcerias entre o Estado e o mercado para suprir a defasagem histórica de acesso ao ensino superior de países periféricos. Há, assim, uma renovação do projeto neoliberal para o ensino superior, que passa a ser incluído como investimento a ser realizado por estes países.

Entretanto, o Banco Mundial recomendou também mudança no financiamento do ensino superior nos países periféricos. As sugestões direcionaram para o financiamento público de instituições privadas, como uma forma de garantir a equidade do acesso, e o incentivo por meio de reformas no ensino superior para que instituições públicas diversificassem suas fontes de renda, por meio da ampliação da autonomia na administração de seus recursos (WORLD BANK, 1999). Para Puello-Socarrás (2011), esta mudança visou submeter o sistema de ensino superior aos ditames do livre comércio global e aos poderes financeiros transnacionais.

Esses movimentos tinham como objetivo sancionar o repasse de recursos públicos para oferta de educação por instituições privadas, bem como o recebimento de recursos privados por organizações públicas, por meio de interações público-privadas, visando consolidar a esfera pública não-estatal. Esta esfera busca capturar aqueles bens públicos que não tenham sido incorporados no ciclo de valorização capitalista ou que, por sua deficiência, se articulam de forma precária com o mercado. Assim, o objetivo não é mais criar estruturas de mercado, mas sim enraizar as forças do mercado para que espaços não-mercantis funcionem como se fossem mercados (PUELLO-SOCARRÁS, 2011).

Através desses mecanismos não há transferência de propriedade da natureza da universidade, mas uma modificação na lógica do seu funcionamento. O novo neoliberalismo não busca transferir a propriedade pública à iniciativa privada, como era característico do velho neoliberalismo, mas atua paralelamente, através da lógica de acumulação sem desapossamento (PUELLO-SOCARRÁS, 2011). Este conceito complementa o de acumulação por espoliação formulado por David Harvey (2014b). Este autor afirma que, no capitalismo contemporâneo, uma pequena elite no comando dos processos políticos, ou seja, do Estado, desenvolveu novos 
mecanismos de acumulação por espoliação, com o objetivo de aumentar o acúmulo de riquezas das classes superiores em contextos de baixo crescimento econômico9?

\begin{abstract}
Esta acumulação por espoliação ${ }^{10}$ adquire múltiplas formas. Mão-de-obra barata é rapidamente saqueada e quanto mais barata e dócil, melhor. As taxas de lucro das empresas norte-americanas são duas vezes mais altas no estrangeiro do que internamente. Os direitos comuns de propriedade (água, território, etc.) estão a ser privatizados. Populações de camponeses desfazem-se dos seus terrenos. O meioambiente é degradado. Patentes de direitos para tudo desde materiais genéticos, sementes, produtos farmacêuticos até ideias permitem extrair dinheiro de populações com baixos rendimentos. Bens fundamentais como a educação e cuidados de saúde são tornados comercializáveis (HARVEY, 2004. n.p.).
\end{abstract}

Na lógica da acumulação sem desapossamento, as universidades públicas não são privatizadas. Nesta nova era, o que importa é a empresarialização e o agenciamento da gestão, ou seja, não importa a posse direta dos bens públicos, mas os mecanismos que permitem introduzir a lógica privada no público. Buscam-se formas para introduzir o empreendedorismo e reproduzir a lógica do mercado sem que isso signifique transformar o caráter da propriedade, que pode permanecer público, assegurando que a gestão e os lucros sejam privados (PUELLOSOCARRÁS, 2011).

No novo neoliberalismo o homem empreendedor é o princípio antropológico do ser humano. O empreendedor é, em si mesmo, a força fundamental na sociedade de mercado, ou seja, é quem guia a produção social assumindo a função de coordenar a divisão do trabalho. $\mathrm{O}$ empreendedor como empresário é o mediador que inova e produz novas combinações entre trabalho e capital (PUELLO-SOCARRÁS, 2008a). A partir dessa concepção de empreendedor, central para o novo neoliberalismo, tem emergido uma série de novas configurações, principalmente, no mundo do trabalho.

O empreendedorismo é um dos pressupostos do modelo Hélice Tríplice, difundido a partir dos anos 1990, e cria uma nova configuração nas universidades, ao vincular o público ao privado para o desenvolvimento de inovações. Na concepção de Etzkowitz, (2003) à universidade é exigida a função empreendedora, pois deve adotar uma postura proativa na

9 Para Harvey (2004) os grupos com rendimentos mais elevados tornaram-se infinitamente mais ricos sob o neoliberalismo, portanto, houve um aumento da desigualdade social.

10 A acumulação por espoliação tornou-se acentuada a partir dos anos 1970 com a emergência da teoria neoliberal. A privatização e a liberalização do mercado foram as principais estratégias do movimento neoliberal (HARVEY, 2014b). Seguindo esta orientação, bens públicos como as universidades foram privatizados em países centrais e periféricos. Na América Latina, a privatização das universidades públicas, como recomendado por esta lógica de "expropriação das terras comuns" (HARVEY, 2014b), teve no Chile, sua maior expressão. Para Puello-Socarrás (2011) a privatização dos ativos públicos é uma característica do neoliberalismo ortodoxo. 
criação de inovações, já que está imersa em ambiente que agrupa conhecimento e capital intelectual. Diz ele: "por um lado, o empreendedorismo acadêmico, é uma extensão das atividades de ensino e pesquisa, por outro a internalização das capacidades de transferência tecnológica, tomando um papel tradicionalmente atribuído exclusivamente ao setor privado" (ETZKOWITZ, 2005, p. 6). Para Etzkowitz (2005), a universidade ao direcionar os processos de inovação assume a principal função na sociedade capitalista. Ali, o argumento Hélice Tríplice é materializado em arranjos como incubadoras, parques e polos tecnológicos, núcleos de inovação tecnológica, etc. Etzkowitz (2010) afirma que "o propósito de uma incubadora é treinar um grupo de indivíduos para trabalhar como uma organização. E a universidade pode fazer esse papel. Isso é mais amplo do que inventar novas tecnologias, é também criar estruturas organizacionais". Ainda, afirma que os escritórios de transferências de tecnologias, os núcleos de inovação e tecnologia (NITs) têm como função, além da geração de patentes, o incentivo ao empreendedorismo (ETZKOWITZ, 2010).

Além disso, as universidades públicas passam a incorporar os princípios dos empreendedorismos nos seus processos de gestão. Para Puello-Socarrás (2008a) o espírito empreendedor tem guiado de forma contundente o arcabouço teórico que visa adaptar a administração pública para a nova era neoliberal. Essa adaptação ocorre através da utilização de ferramentas gerenciais provenientes da administração privada e tem como objetivo construir uma governança neoliberal (empreendedora), tornando o mercado o paradigma exclusivo da produção social (PUELLO-SOCARRÁS, 2008a). Para Misoczky, Abdala e Damboriarena (2017, p. 192) o gerencialismo é "a matriz teórico-ideológica que oferece o suporte operacional para o avanço do projeto neoliberal”, já que por meio dele é possível a "abertura de novas frentes para acumulação de capital dentro e fora da máquina de Estado, seja por meio de transformações internas ou de relações com organizações privadas".

Newnan e Clarke (2012, p. 355) localizam o gerencialismo como "uma formação cultural e um conjunto distinto de ideologias e práticas que formavam um dos sustentáculos do novo acordo político [...]". O gerencialismo tornou-se essencial nos processos de reformas ocorridas nas décadas de 1980 e 1990, introduzindo o "ethos de negócios do setor privado no Estado e no setor público" (NEWMAN; CLARKE, 2012, p. 358). Exigia-se que o desempenho do Estado, nas funções que não foram privatizadas, fossem orientadas por parâmetros do mercado. Insere-se como prerrogativa de tomada de decisão, a eficiência em detrimento de outros valores públicos. 
No gerencialismo, os gerentes assumem um papel central, pois representam o profissionalismo, o empreendedorismo e o dinamismo. Eles seriam capazes de introduzir nas organizações públicas boas práticas em negócios, que levariam ao controle prático dos custos, visando aumentar a eficiência através da intensificação do trabalho (NEWMAN; CLARKE, 2012). Introduz, desta forma, na organização do Estado um ideário que prega eficiência, produtividade, aproximação do serviço ao cliente, flexibilidade, inovação, empoderamento da figura do gestor e o empreendedorismo no serviço público (CLARKE; NEWMAN, 2012).

Segundo Mancebo, Maués e Chaves (2006) o modelo gerencial direcionou a implementação de cinco princípios no ensino superior: (a) a racionalização de recursos, diminuindo a centralidade do Estado na manutenção da educação; (b) a adoção de avaliações gerenciais que abrangem o controle do sistema educativo; (c) a flexibilização de gestão, justificada pela necessidade de ampliação do sistema, envolvendo a diversificação dos estabelecimentos de ensino; (d) a descentralização gerencial, pela qual os principais parâmetros educacionais continuam a ser estabelecidos, de forma concentrada, num núcleo estratégico, mas com descentralização da gestão administrativa; (e) a privatização dos sistemas educacionais, de forma direta e indireta através (des)investimento do Estado no ensino superior público.

Além disso, o empreendedorismo, como força fundamental de uma sociedade de mercado, cria novas configurações no mundo do trabalho. O empreendedor não é nem um trabalhador, nem um capitalista (PUELLO-SOCARRÁS, 2008a). Defende-se a retórica de que ocupa, no mercado, uma posição privilegiada em relação ao trabalhador, já que possui autonomia e liberdade para escolher quais atividades laborais pretende realizar. Esse princípio impulsiona o crescimento de trabalhadores que abandonam os postos de trabalho tradicionais para tornarem-se trabalhadores por conta própria, ou seja, desprovidos de direitos sociais (PUELLO-SOCARRÁS, 2008b). A lógica do empreendedorismo também pode ser vista nas alterações em relação à carreira docente, tanto em universidades privadas quanto públicas.

No Brasil, a ampliação do acesso criou novos postos de trabalho no ensino superior; entretanto, esse crescimento tem como característica a flexibilização dos contratos trabalhistas, principalmente nas universidades privadas (BOSI, 2007). Nas universidades públicas, diversas são as mudanças observadas nos últimos 25 anos no âmbito do trabalho docente, como a mudança nas regras da remuneração, o aumento de horas-aula semanais em função da avaliação, o aumento do número de alunos em relação aos docentes, com o objetivo de tornar as organizações universitárias mais eficientes (BOSI, 2007) na lógica gerencial. 
Nas atividades de pesquisa, o recente direcionamento das instituições de ensino superior para a produção de inovação tem gerado mudanças nas condições de trabalho, principalmente nas universidades públicas, provocando sua intensificação (OLIVEIRA; FERREIRA; MORAIS, 2015). A carreira de docente, uma vez que é orientada pela pesquisa, que basicamente depende de financiamento externo, exige que o professor desenvolva a habilidade de captador de recursos, ou seja, o espírito empreendedor. Neste modelo de financiamento, o Estado estimula a competição, "através do financiamento individual externo e do sistema meritocrático, gera o esgarçamento do vínculo social e conflitos interpessoais, criando, muitas vezes, um clima de trabalho desfavorável à integração do conhecimento" (LEMOS, 2011, p.118). Todos esses movimentos de flexibilização e precarização do trabalho nas universidades tem como princípio norteador a ampliação da autonomia e da liberdade individual do docente para buscar fontes alternativas de recurso, oriundo da ideia de empreendedorismo (PUELLOSOCARRÁS, 2008b).

Em uma dimensão tática, o novo neoliberalismo acadêmico se manifesta, então, pelo conjunto de recomendações para reformas nos sistemas de ensino superior dos países periféricos que visaram: a) criar políticas inclusivas no ensino superior, para atenuar os efeitos sociais gerados pelo neoliberalismo ortodoxo; b) flexibilizar a formação, por meio da criação de diferentes tipos de instituições e cursos, criando as condições para adaptar a formação da força de trabalho às novas exigências, bem como para o fortalecimento do mercado de ensino superior nos países periféricos; c) modificar o financiamento do ensino superior, ao permitir o investimento de organizações privadas com fins lucrativos nas universidades públicas e que recursos públicos sejam destinados as instituições privadas; c) estabelecer o empreendedorismo, como cultura a ser disseminada nos processos de ensino, pesquisa, extensão e gestão das universidades; d) propagar o gerencialismo como forma de adequar as instituições públicas ao mercado, uma vez que esse é o paradigma exclusivo de produção social; e) flexibilizar e precarizar as relações de trabalho nas IES, via ampliação da autonomia e liberdade individual do docente para buscar fontes alternativas de recurso, oriundos da ideia de empreendedorismo.

\section{NOVO NEOLIBERALISMO ACADÊMICO NO BRASIL}

As mudanças na organização do ensino, a partir da ampliação do acesso às universidades públicas federais, e da pesquisa e da extensão a partir das políticas de incentivo à inovação nas 
universidades públicas federais nos Governo Lula (2003-2010) e Dilma (2011-2016), convergem com as mudanças realizadas nas recomendações realizadas para os países periféricos pelo Banco Mundial na área do ensino superior a partir de 1999.

O ensino superior não era prioridade para os países periféricos no neoliberalismo ortodoxo; eles deveriam destinar os recursos orçamentários deste setor prioritariamente para o nível básico. Entretanto, a partir de 1999, o ensino superior foi incluído nos investimentos que deveriam ser realizados pelos países periféricos para que estes pudessem alcançar um grau maior de crescimento econômico. Nos Governos Lula (2007-2010) e Dilma (2011-2016), foram criadas novas universidades e ampliadas as vagas nas universidades federais tradicionais, por meio do REUNI. Apesar da resistência interna em algumas universidades, o primeiro Relatório do REUNI (2008) mostrou que das 54 universidades federais existentes ao final de 2007, apenas a Universidade Federal do $\mathrm{ABC}$ não aderiu ao programa, pois ela já adotava as inovações pedagógicas propostas pelo Programa. Em 2015, último ano em que o Ministério da Educação (MEC) destinou recursos para as universidades por intermédio do REUNI, o Programa se aproximou da meta de um milhão de matrículas nas universidades federais.

As políticas de ampliação do acesso criaram, no período de 2003-2015, 19 universidades federais, o que representou um crescimento de 43,2\% no número de instituições, $129,64 \%$ na oferta de cursos, $99,8 \%$ no número de ingressos anuais, $88,74 \%$ nas matrículas e $43,61 \%$ nos concluintes. O aumento no número de matrículas de 2007-2015 foi de 72,16\%, um crescimento superior ao planejado.

O REUNI recomendava que as universidades públicas deveriam realizar uma reestruturação acadêmico-curricular. O bacharelado interdisciplinar foi um dos modelos de cursos adotados para a reestruturação acadêmico-curricular, introduzindo a formação por ciclos. Os bacharelados interdisciplinares foram implementados em 18 das 63 universidades federais, cobrindo $28,5 \%$ do total de instituições. A expansão dos BIs segue as orientações do BM para a diversificação dos cursos ofertados pelas IES dos países periféricos. A criação dos bacharelados interdisciplinares tanto no Brasil como nos demais países emerge da necessidade característica do capitalismo tardio de uma formação mais abrangente, que permita adaptação às mudanças e às habilidades politécnicas em função da aceleração da inovação tecnológica (MANDEL, 1982). Além disso, tinha como objetivo criar flexibilidade e padronização da formação, permitindo que alunos do ensino superior tenham uma maior mobilidade. A velocidade com que surgem as inovações faz com que surjam novas necessidades de qualificação do trabalhador ao longo de sua carreira. 
Além dos bacharelados interdisciplinares, a ampliação dos cursos superiores de tecnologia foi outra forma de diversificação da oferta de cursos superiores pelas universidades federais. O ensino superior tecnológico representava, em 2003, apenas 6,0\% do total de matrículas no ensino federal, e passou para $12 \%$ em 2015. Houve, entre 2009-2015, o aumento da oferta de cursos tecnológicos $(33,04 \%)$ e de matrículas nas universidades federais $(17,84 \%)$. O ensino tecnológico ficou concentrado em Institutos Federais e Centros Federais de Educação Tecnológica, que ampliaram a oferta de cursos em $329,37 \%$ e $300,78 \%$, respectivamente, de matrículas entre 2003-2015.

As características dos cursos superiores de tecnologia - o encurtamento e a especialização restrita da formação dos alunos - fizeram com que enfrentassem resistência da comunidade acadêmica das universidades federais e ficassem concentrados, em sua maioria, nas universidades novas, criando outra distinção entre estas e as universidades federais tradicionais. Essa distinção vai ao encontro daquilo que foi proposto pelo documento $\mathrm{La}$ educación en los países en desarrollo: peligros y promesas (2000), do Banco Mundial em parceria com a UNESCO, ou seja, a criação de um modelo híbrido de ensino superior, em que existam instituições de excelência em pesquisa e instituições direcionadas à formação para o mundo do trabalho, ou seja, o direcionamento da formação de acordo com competências exigidas pelo mercado. O objetivo dos modelos híbridos é oferecer diferentes tipos de formação nos sistemas de ensino superior.

Outra forma de flexibilizar a formação aconteceu por meio da regulamentação e ampliação da oferta de cursos a distância. Em 2003, nas universidades federais brasileiras havia apenas 24 cursos na modalidade; em 2014, já eram 267 cursos, com 87 mil matrículas. Quando considerados os números totais de matrícula, os cursos EaD passaram de 2,71\% do total de alunos nas universidades federais para 8,39\% em 2014. O crescimento do número de matrículas da graduação $\mathrm{EaD}$ foi de $497,54 \%$, enquanto que a presencial cresceu $81,66 \%$ no período. Em 2015, havia 710 polos com oferta de cursos pelas universidades federais.

Nas universidades públicas, os cursos são operacionalizados por meio da Universidade Aberta do Brasil (UAB), vinculada ao MEC, que permite a oferta de cursos em polos através de convênios com prefeituras. A grande escala do modelo UAB faz com que haja um aumento da relação aluno/professor nos cursos a distância em relação aos cursos presenciais. Esse aumento dificulta a articulação entre ensino, pesquisa e extensão nesse modelo de oferta. Os alunos, em sua maioria, não participam de atividades de pesquisa e extensão, restringindo sua aprendizagem às atividades de ensino. Além disso, a UAB é um mecanismo de gestão de 
projetos, já que a oferta de cursos é definida por meio de editais do Ministério da Educação. Os projetos pedagógicos têm uma estrutura curricular previamente definida, proposta pelo MEC, havendo uma limitada possibilidade de adaptação pelos docentes das universidades federais, que se tornam executores de uma proposta de ensino padronizada.

A ampliação do acesso ao ensino público, por meio da EaD, também está em consonância com as diretrizes propostas pelo BM no Documento estratégico del Banco Mundial: La educación en América Latina y el Caribe, de 1999, dentre as estratégias sugeridas para ampliação do ensino superior que recomendavam o uso da tecnologia, por meio de programas de aprendizagem a distância, o que possibilitaria ampliar as vagas no ensino superior público com custos mais baixos. A flexibilização imposta pelo modelo EaD vai ao encontro da atual necessidade neoliberal de formação da força de trabalho, já que o homem empreendedor, princípio antropológico do novo neoliberalismo (PUELLO-SOCARRÁS, 2008a), é o responsável pela sua própria sobrevivência, adentrando ao mundo do trabalho de forma flexível, ou seja, sem um vínculo formal com as organizações.

Além da flexibilização da formação, a ampliação do acesso ao ensino superior público foi acompanhado de políticas de inclusão social. O Programa Nacional de Assistência Estudantil (PNAES) foi criado em dezembro de 2007, regulamentado pelo Decreto ${ }^{\circ} 7.234$, de 19 de julho de 2010. O programa tinha como objetivo auxiliar os estudantes matriculados em universidades federais em cursos presenciais de graduação, como forma de garantir o acesso, a permanência e a conclusão dos estudantes de baixa renda. O investimento no PNAES passou de 18,9 milhões em 2011, primeiro ano do programa, para 941 milhões em 2016, quando foram concedidas 2,3 milhões de benefícios entre as diferentes modalidades de bolsas.

No que tange à inclusão, foi aprovada a Lei $\mathrm{n}^{\mathbf{0}}$ 12.711, de 29 de agosto de 2012, que representou um marco em relação ao acesso ao ensino superior no Brasil, considerado historicamente elitista. A referida lei estabeleceu reserva de $50 \%$ das vagas para estudantes oriundos de famílias com renda igual ou inferior a 1,5 salário mínimo per capita (BRASIL, 2012). Os dados do total de jovens entre 18 e 24 anos no ensino superior mostram que a cobertura total passou de 14,9\% em 2004, para 18,4\% em 2015 (BRASIL, 2017).

Entretanto, quando se analisa a cobertura por cor, percebemos que a ampliação foi de $16,6 \%$, em 2004, para 26,5\%, em 2010, entre os jovens brancos, entre 18 e 24 anos, enquanto que dos negros passou de 5\% para 12,8\% (BRASIL, 2017). Apesar da política de cotas, ainda há uma diferença grande entre o acesso de brancos e negros. 
Os dados do acesso de classes sociais de baixa renda, por meio da criação de políticas de inclusão e de assistência estudantil nas universidades federais mostram que a ampliação do acesso, por meio do REUNI e do PNAES, ao mesmo tempo em que atendeu a uma demanda histórica por ampliação das vagas públicas, seguiu as recomendações do Banco Mundial, já que a inclusão foi um tema central nas modificações nas orientações para o ensino superior nos documentos publicados desde 1999.

A ampliação, por meio da inclusão, possibilita a melhora da condição de vida dos beneficiários dos programas, bem como elevação da renda individual dos egressos que conseguem acessar o mercado de trabalho. Segundo dados da Education at a Glance 2018, o rendimento de trabalhadores brasileiros com ensino médio, na faixa de 25 a 64 anos, é 2,5 vezes menos do que trabalhadores com graduação e 4,5 vezes menor que trabalhadores com pósgraduação (OECD, 2018). Esses dados evidenciam que as políticas inclusivas têm um papel importante da melhoria da renda média dos trabalhadores egressos do ensino superior.

Os benefícios da política de ampliação associada com políticas inclusivas têm efeitos tanto do ponto de vista individual, como estratégico para o País, visto que amplia sua oferta de mão de obra com ensino superior. A inclusão social no ensino superior foi uma das estratégias de renovação do neoliberalismo para evitar o esgotamento de seus próprios limites (PUELLOSOCARRÁS, 2013), pois diminui a pressão social por oportunidades educacionais. A estruturação da política de ampliação do acesso possibilitou a entrada na universidade de pessoas oriundas das classes $\mathrm{C}$ e $\mathrm{D}$, que passaram a representar $56,43 \%$ do total de matrículas enquanto que as classes A e B passaram a representar apenas 30, 36\% em 2014. Entretanto, os efeitos positivos das políticas inclusivas foram acompanhados da precarização da oferta por meio da formação profissional em grande escala $(\mathrm{EaD})$, bem como pelo encurtamento e flexibilização da formação (BIs/tecnólogos), pois, por meio da precarização, é possível reduzir os custos com o ingresso das classes sociais de baixa renda nas universidades públicas.

Além disso, as universidades tornaram-se espaço de formação para o empreendedorismo no novo neoliberalismo. As universidades públicas federais estruturaram programas de formação para o empreendedorismo, em que são ofertadas disciplinas voltadas para a temática em todos os níveis de formação (graduação e pós-graduação), com o objetivo de contemplar grande parte dos egressos do ensino superior. $\mathrm{O}$ empreendedorismo não ficou restrito a ações de ensino, ele adentrou as universidades em todas suas dimensões. As instituições criaram estruturas (empresas juniores, incubadoras, parques tecnológicos) para preparar egressos formatados às necessidades do mercado de trabalho no novo neoliberalismo, ou seja, estruturas 
que permitam condicionar os alunos à flexibilização das relações de trabalho, já que não há garantias de empregos para todos os egressos com o aprofundamento do neoliberalismo.

Também ocorreram novas formas de apropriação do público pelo privado mediante a incorporação de práticas gerenciais na organização nas atividades de ensino, pesquisa e extensão. A modificação da lógica de gestão tem como fim aumentar a eficiência das organizações públicas, conforme os parâmetros do mercado, reduzindo os custos do ensino superior público por meio da adoção de mecanismos de controle e pela intensificação do trabalho.

O gerencialismo, como estratégia operacional do neoliberalismo na administração pública, se materializou nas universidades públicas federais por meio: (a) das relações entre o MEC e as universidades, ao estabelecer o contrato de gestão como mecanismo de ampliação do acesso ao ensino público (REUNI e Sistema UAB), atrelando o financiamento das universidades públicas ao seu desempenho; (b) da criação de estruturas gerenciais provisórias para oferta de cursos por demandas específicas, ou seja, do estabelecimento da gestão de projetos (Sistema UAB), o que gera descontinuidade na oferta de vagas públicas; (c) das relações público-privadas, já que as universidades públicas, por meio de contratos de interações acadêmicas, precisam modificar sua lógica de gestão, principalmente da organização da pesquisa, para adequar-se aos interesses e aos objetivos das empresas; (d) pela política de gestão de pessoas que importou para as universidades públicas ferramentas de gestão típicas da iniciativa privada (avaliação por competências e a avaliação de desempenho); (e) pela introdução da cultura do planejamento estratégico (PDI), que reduz os problemas acadêmicos a questões de planejamento e avaliação.

O novo neoliberalismo acadêmico, assim, utiliza-se do gerencialismo como um meio para que os resultados gerados pelas universidades públicas possam ser apropriados para fins privados, bem como cria as condições para que o Estado possa ser desresponsabilizado pela manutenção das universidades públicas, já que esses mecanismos possibilitam a redução dos custos com o ensino público. Outro aspecto que caracteriza novo projeto neoliberal para o ensino superior é a política de financiamento. A expansão do orçamento, por meio do REUNI, não acompanhou o crescimento das matrículas na graduação e na pós-graduação. Além disso, aumentou os recursos públicos destinados para as organizações privadas por meio da criação do PROUNI e expansão do FIES.

Para a pesquisa, os recursos aplicados diretamente por meio de órgãos de fomento, igualmente, não acompanharam a ampliação dos cursos de pós-graduação nas universidades 
públicas federais. Ainda, a distribuição orçamentária dos fundos públicos criados desde o Governo Fernando Henrique Cardoso para o financiamento da pesquisa foi alterada, privilegiando os editais em que os recursos são direcionados para empresas, para que estas realizem projetos em parcerias com as universidades na busca de inovações. A redução proporcional dos orçamentos para a realização das atividades de ensino, pesquisa e extensão, criou as condições para que as universidades públicas buscassem fontes alternativas de recursos. Novas fontes de financiamento foram obtidas por meio da: (a) adesão ao Sistema UAB, para ofertas de cursos por demanda específica do MEC, sem a necessidade de ampliar diretamente o orçamento das universidades; (b) oferta de cursos (pós-graduação, capacitação e extensão) pagos; (c) prestação de serviços de consultoria; e (d) prestação de serviços de P\&D para empresas nacionais e multinacionais, por meio de suas subsidiárias, geralmente, em projetos de adaptação tecnológica. Todas essas ações demandaram que a universidade reorganizasse as atividades de ensino, pesquisa e extensão em direção da implementação da nova governança neoliberal.

A apropriação dos resultados gerados pelas universidades públicas acontece, ainda, por meio da precarização, flexibilização e intensificação do trabalho. Os mecanismos utilizados foram: (a) aumento da relação aluno/professor nas universidades públicas federais (REUNI), principalmente por meio da expansão da pós-graduação; (b) expansão do acesso com base em projetos (Sistema UAB), o que não garante o fluxo contínuo de recursos, bem como flexibiliza o pagamento dos docentes, realizado por meio de bolsas pagas diretamente pelo MEC, desprovido de outros direitos, e cria formas de contratação de servidores temporários (tutores), sem nenhum tipo de vínculo empregatício com as universidades públicas federais; (c) instituição do novo plano de carreira do magistério público federal que: i) tornou a carreira docente federal pouco atrativa para pesquisadores altamente qualificados; ii) dificultou a mobilidade de pesquisadores, uma vez que fez com que os novos ingressantes, independentemente da formação, fossem enquadrados na base da carreira; ii) flexibilizou a dedicação exclusiva ao permitir remuneração complementar; iii) instituiu a avaliação de desempenho baseada, principalmente, em critérios quantitativos, intensificando o trabalho nas universidades federais; e (d) aprovou o novo MLCT\&I que: i) flexibilizou os contratos de trabalho de dedicação exclusiva nas universidades públicas, ao permitir remuneração complementar por meio de projetos de interação com empresas; ii) possibilitou a contratação de pesquisadores nacionais ou estrangeiros para atuação em projetos de pesquisa com prazo determinado nas universidades públicas; iii) promoveu a intensificação do trabalho do 
pesquisador ao subordinar as atividades de pesquisa à demanda das empresas, ou seja, subverteu o trabalho docente à busca de resultados econômicos.

Assim, no novo neoliberalismo acadêmico a precarização e a flexibilização das relações de trabalho nas universidades federais têm o objetivo de ampliar a autonomia e a liberdade individual do docente para buscar fontes alternativas de recurso, os seja, torná-los empreendedores acadêmicos.

Portanto, o projeto neoliberal para o ensino superior dos países periféricos teve suas táticas renovadas e sua implementação, por meio da ampliação do acesso e das políticas de incentivo à inovação, fizeram emergir o novo neoliberalismo acadêmico no ensino superior brasileiro. Entretanto, a alteração aparente no projeto para as universidades públicas federais no novo neoliberalismo foi encoberta pela retórica da valorização do ensino público nos Governos Lula (2007-2010) e Dilma (2011-2016), condizentes com a perspectiva de consenso de classes adotada.

As mudanças no projeto neoliberal para os sistemas de educação dos países periféricos, caracterizadas como novo neoliberalismo acadêmico, estão conectadas com os movimentos do capital. A ampliação do acesso ao ensino superior privado verificada, nos últimos 15 anos, busca novas frentes de lucratividade em contextos de baixo crescimento industrial, dado o potencial de crescimento do mercado brasileiro em função da baixa cobertura do ensino superior no País. Nas universidades públicas federais, foco deste estudo, a ampliação foi acompanhada pelo encurtamento e a flexibilização da formação decorrentes da exigência do próprio capital, pois é possível "baratear" a mão-de-obra qualificada na periferia do capitalismo, devido à ampliação da oferta de trabalhadores diplomados.

Além disso, o novo neoliberalismo acadêmico, ao articular ampliação do acesso ao ensino superior e promover a inovação como uma das funções das universidades públicas, por meio do relacionamento universidade-empresa, cria novos mecanismos para integrar as universidades públicas (de excelência), que desenvolvem pesquisa de alta tecnologia, aos mecanismos de acumulação por espoliação, tornando-as espaços: (a) de formação de mão-deobra altamente qualificada (mestres e doutores) para os países centrais que recrutam pesquisadores brasileiros para trabalhar em suas empresas e universidades; (b) de adaptação tecnológica, para as empresas nacionais, que continuam adquirindo tecnologia dos países centrais; e (c) de desenvolvimento tecnológico para empresas multinacionais, que buscam terceirizar parte do $\mathrm{P} \& \mathrm{D}$ para os países periféricos, com intuito de reduzir os custos com o desenvolvimento das tecnologias, aumentando os lucros da renda tecnológica. 


\section{CONSIDERAÇÕES FINAIS}

A descrição e a análise da política de ampliação do acesso e da política de incentivo à inovação dos Governos Lula (2003-2010) e Dilma (2011-2016), longe de indicar, uma inflexão antineoliberal, reproduziram as recomendações dos documentos dos organismos internacionais que orientaram as reformas nos países periféricos. As eventuais alterações naqueles documentos se adequam a correções de rumo no projeto neoliberal e, no setor da educação, conformam o que Puello-Socarrás (2011) caracterizou como novo neoliberalismo acadêmico.

Além das alterações na forma de financiamento, identificada por Puello-Socarrás (2011), o novo neoliberalismo acadêmico envolve alterações no ensino, na pesquisa e na extensão das universidades públicas e apresenta aspectos contraditórios. As características do novo neoliberalismo acadêmico, a partir da realidade brasileira, englobam a criação de políticas inclusivas, que ampliaram a participação dos mais pobres nas IFES; a flexibilização da oferta de cursos que, por um lado, reduziu os custos das políticas inclusivas, por outro adequou a formação às novas exigências do mundo do trabalho; o direcionamento das atividades de ensino, pesquisa e extensão para o empreendedorismo; a adoção do gerencialismo na organização das atividades de ensino, pesquisa e extensão das universidades públicas; e a precarização, flexibilização e intensificação o trabalho nas universidades públicas federais. A atualização do projeto neoliberal para a educação não alterou, até agora, a natureza pública das IFES, mas avançou numa espécie de privatização implícita ou indireta, ou seja, representa um mecanismo de acumulação sem desapossamento (PUELLO-SOCARRÁS, 2011).

O novo neoliberalismo acadêmico ajuda a compreender, ainda, o modo pelo qual as universidades públicas tiveram reforçada sua operação, estrutural e dinamicamente, como uma entidade especializada e integrada aos circuitos de reprodução do capital. Ao mesmo tempo em que a ampliação do acesso a instituições públicas contribui para a redução dos custos com a qualificação da mão-de-obra com formação superior, também, fortalece as instituições privadas com recursos públicos, já que as vagas e unidades públicas são insuficientes. Ou seja, a valorização e o incentivo à formação em nível superior contribuiu decisivamente para a criação de um dos maiores mercados de ensino privado do mundo no Brasil. A ampliação do acesso ao ensino superior brasileiro, concentrada no ensino privado com fins lucrativos, torna o mercado educacional uma nova frente de aplicação do capital excedente, em busca de uma maior rentabilidade em um contexto de baixo crescimento. 
Ademais, a política de incentivo à inovação permite que as empresas estrangeiras se beneficiem da produção de $C \& T$ realizadas, em sua quase totalidade pelas universidades públicas e as nacionais (que pouco se interessam realmente por inovação) que as utilizem para realizar a simples adaptação tecnológica, característica do desenvolvimento dependente.

Esse é um movimento que deve se intensificar nos próximos anos, uma vez que o MLCT\&I foi regulamentado recentemente, pelo Decreto $\mathrm{n}^{\circ}$ 9.283, de 7 de fevereiro de 2018; e as universidades devem elaborar novas normas nessa direção. Essa regulamentação acontece em meio à intensificação da crise de financiamento vivenciada pelas universidades nos últimos três anos, com cortes orçamentários realizados no ensino superior e nos investimentos em C\&T pelo Governo Temer (2016-2018) e no primeiro ano do Governo Bolsonaro, acompanhada pelo retorno da proposta do fim da gratuidade das universidades públicas federais. No relatório "Um ajuste justo - propostas para aumentar eficiência e equidade do gasto público no Brasil", publicado em novembro de 2017, o Banco Mundial voltou a defender que as universidades públicas deveriam ser pagas, por apresentarem elevados custos e beneficiarem, em grande parte, alunos oriundos de camadas sociais mais elevadas. Na proposta, está previsto que o Governo brasileiro deverá criar mecanismos de financiamento público, tal como os existentes no ensino privado (FIES, PROUNI), para subsidiar o acesso da população mais pobre a essas instituições.

O novo momento político brasileiro encontrou prontas as condições para o aprofundamento da precarização do ensino superior público bem como para a sua funcionalização ao projeto privatizante e subalterno que ora se tenta implementar. As transformações do neoliberalismo continuam em curso e podem emergir em novos projetos para as universidades públicas, o que torna a compreensão dessas mudanças determinante para a intensificação do movimento de defesa da universidade pública.

\section{REFERÊNCIAS}

BORGES, Maria Creusa de Araújo. A educação superior numa perspectiva comercial: a visão da Organização Mundial do Comércio. Revista Brasileira de Política e Administração da Educação, Goiânia, v.25, n.1, p. 83-91, jan./abr., 2010.

BOSI, Antônio de Pádua. A precarização do trabalho docente nas instituições de ensino superior no Brasil nos últimos 25 anos. Educação \& Sociedade, Campinas, vol. 28, n. 101, p. 1503-1523, set./dez., 2007.

BRASIL. Decreto n. 6.096, de 24 de abril de 2007. Institui o Programa de Apoio a Planos de Reestruturação e Expansão das Universidades Federais - REUNI. Brasília: Diário Oficial da União, 25 abr. 2007. Disponível em:

(c) $(1) \Theta$ REAd | Porto Alegre - Vol. 25 - N. ${ }^{\circ} 3$ - Setembro / Dezembro 2019 - p. 6 - 35 
http://www.planalto.gov.br/ccivil_03/_ato2007-2010/2007/decreto/d6096.htm Acesso em 30 jun. 2017.

BRASIL. Mistério da Educação. Censo Educação Superior. Brasília: INEP/MEC, 2017. Disponível em: http://portal.inep.gov.br/web/guest/censo-da-educacao-superior Acesso em 15 set. 2019.

BRASIL. Lei n. 11.096, de 13 de janeiro de 2005. Institui o Programa Universidade para Todos - PROUNI, regula a atuação de entidades beneficentes de assistência social no ensino superior; [...]. Diário Oficial da União. Brasília, DF, 14 jan. 2005. Disponível em: http://www.planalto.gov.br/ccivil_03/_ato2004-2006/2005/lei/111096.htm Acesso em 15 abr. 2016.

BRASIL. Mistério da Educação. Plano Nacional de Pós-Graduação (PNPG) 2005-2010 Brasília: Ministério da Educação. Brasília: MEC, 2004. Disponível em: hhttps://www.capes.gov.br/images/stories/download/editais/PNPG_2005_2010.pdf Acesso em 25 ago. 2017.

BRASIL. Mistério da Educação. Diretrizes Gerais do Programa de Apoio a Planos de Reestruturação e Expansão das Universidades Federais: Reuni. Brasília: MEC, 2007. Disponível em: http://portal.mec.gov.br/sesu/arquivos/pdf/diretrizesreuni.pdf Acesso em 15 ago. 2018.

BRASIL. Mistério da Educação. Censo Nacional da Educação Superior. Brasília: INEP/SEED/MEC, 2017. Disponível em: http://portal.inep.gov.br/censo-da-educacaosuperior Acesso em 15 dez. 2017.

BRASIL. Lei $\mathrm{n}^{\circ} 12.711$, de 29 de agosto de 2012. Dispõe sobre o ingresso nas universidades federais e nas instituições federais de ensino técnico de nível médio e dá outras providências. Brasília: Diário Oficial da União, 30 ago. 2012. Disponível em: http://www.planalto.gov.br/ccivil_03/_ato2011-2014/2012/lei/112711.htm Acesso em 15 ago. 2017.

BRASIL. Lei n. 13.243, de 11 de janeiro de 2016. Dispõe sobre estímulos ao desenvolvimento científico, à pesquisa, à capacitação científica e tecnológica e à inovação[...]. Brasília: Diário Oficial da União, 12 jan. 2016. Disponível em: http://www.planalto.gov.br/ccivil_03/_ato2015-2018/2016/lei/113243.htm. Acesso em 30 abr. 2016.

BRESSER-PEREIRA, Luiz Carlos. O novo desenvolvimentismo e a ortodoxia convencional. São Paulo em Perspectiva, v. 20, n. 3, pp. 5-24, 2006.

CUNHA, Luiz Antonio Constant Rodrigues da. O ensino superior no octênio FHC. Educação \& Sociedade, Campinas, vol. 24, n. 82, pp. 37-61, abril, 2003.

ETZKOWITZ, Henry. Reconstrução criativa: Hélice tripla e inovação regional. Revista Inteligência Empresarial, Rio de Janeiro, n. 23, p.02-44, abr/mai/jun, 2005. 
ETZKOWITZ, Henry. Hélice Tríplice: metáfora dos anos 90 descreve bem o mais sustentável modelo de sistema de inovação. Revista Conhecimento e Inovação, Campinas, v. 6, n. 1, 2010.

FAÉ, Rogério; GOULART, Sueli; ABDALA, P. Estratégia nacional de desenvolvimento nos governos Lula e Dilma: transformação neoliberal. Revista Pensamento Contemporâneo em Administração (UFF), v. 10, p. 1-18, 2016.

GREGÓRIO, José Renato Bez de. O Papel do Banco Mundial na Contra Reforma da Educação Superior no Brasil: uma análise dos documentos que precederam o REUNI. Trabalho Necessário, Niterói, v. 14, p. 1-26, 2012.

HARVEY, David. O enigma do capital: e as crises do capitalismo. São Paulo, SP: Boitempo, 2011.

HARVEY, David. O neoliberalismo: história e implicações. São Paulo: Loyola, 2014a.

HARVEY, David. O novo imperialismo. São Paulo: Edições Loyola, 2014b.

LEHER, Roberto. Capitalismo dependiente y Educación: propuestas para la problemática universitaria. In: Roberto Leher. (Org.). Por una reforma radical de las universidades latinoamericanas. $1^{\mathrm{a}}$ ed. Rosário: Homo Sapiens Ediciones, 2010. P. 19-93.

LEMOS, Denise. Trabalho docente nas universidades federais: tensões e contradições. Cad. CRH, Salvador, v.24, n. esp.1, 2011.

LIMA, Kátia Regina de Souza. O Banco Mundial e a educação superior brasileira na primeira década do novo século. Revista Katálysis, Florianópolis, v. 14, p. 86-94, 2011.

MANCEBO; Deise, MAUÉS, Olgaíses, CHAVES, Vera Lúcia Jacob. Crise e reforma do Estado e da Universidade Brasileira: implicações para o trabalho docente. Educar, Curitiba, n. 28, p. 37-53, 2006.

MANDEL, Ernest. O Capitalismo tardio. São Paulo: Abril Cultural, 1982.

MINTO, Lalo Watanabe. Economia da Educação. Disponível em:

http://www.histedbr.fe.unicamp.br/navegando/glossario/verb_c_economia_da_educacao.htm\# _ftn1 Acesso em 04 jan. 2019.

MISOCZKY, Maria Ceci; ABDALA, Paulo Ricardo Zilio; DAMBORIARENA, Luiza. A trajetória ininterrupta da reforma do aparelho de Estado no Brasil: Continuidades nos marcos do neoliberalismo e do gerencialismo. Administração Pública e Gestão Social, Viçosa, v.9, n.3, p.184-193 jul.-set, 2017.

NEWMAN, Janet; CLARKE, Jonh, Gerencialismo. Educação e Realidade, Porto Alegre, v. 37, n. 2, p. 353-381, maio/ago., 2012.

OLIVEIRA, José Ferreira; FERREIRA, Adriano de Melo; MORES, Karine Nunes de. A política e a cultura de Inovação na Educação Superior no Brasil. In: CATANI, Afrânio, 
Mendes; OLIVEIRA, José Ferreira. Educação Superior e Produção de Conhecimento: utilitalismo, internacionalização e novo contrato social. Campinas: Mercado das Letras, 2015.

RODRIGUES, José. Da teoria do Capital Humano à empregabilidade: um ensaio sobre as crises do Capital e a Educação Brasileira. Trabalho e Educação, Belo Horizonte, n. 2, ago./dez., 1997.

PINTO, Eduardo Costa; BALANCO, Paulo. Transformações do capitalismo contemporâneo e os impactos para a América Latina: retrospectivas, mudanças e perspectivas. Texto para discussão 03. Instituito de Economia da UFRJ. Rio de Janeiro, 2013.

PUELLO-SOCARRÁS, José Francisco. Nueva Gramática del Neo-liberalismo. Itinerarios teóricos, trayectorias intelectuales, claves ideológicas. Bogotá: Universidad Nacional de Colombia, Facultad de Derecho, Ciencias Políticas y Sociales, 2008a.

PUELLO-SOCARRÁS, José Francisco. ¿Un Nuevo Neo-liberalismo? Emprendimiento y Nueva Administración de lo público. Revista Administración \& Desarrollo, Bogotá, n. 49, pp. 7-39, $2008 b$.

PUELLO-SOCARRÁS, José Francisco. Un ensayo sobre la depravación total. Nuevo Neoliberalismo Académico y Capitalismo 'por posesión, Revista Izquierda, Bogotá, n. 14, ago., pp. 18-23, 2011.

PUELLO-SOCARRÁS, José Francisco. Ocho tesis sobre el neoliberalismo (1973-2013). In: Ramírez, Hernán (org.). O neoliberalismo sul-americano em clave transnacional: enraizamento, apogeu e crise. São Leopoldo: Oikos - Unisinos, p. 13-57, 2013.

PUELLO-SOCARRÁS, José Francisco. Desarrollo: Paleontología (política) de una idea (neoliberal) Development: A (Political) Paleontological Study of a (Neoliberal) Idea. Anuário en Etudios Políticos Latinoamericanos, v. 2, Bogotá, Colombia, 2015.

WORLD BANK. Más allá del Consenso de Washington: la hora de la reforma. New York: World Bank, 1998.

WORLD BANK. Documento estratégico del Banco Mundial: La educación en América Latina y el Caribe. New York: World Bank, 1999.

WORLD BANK. Construir Sociedades de Conocimiento: Nuevos Desafíos para la Educación Terciaria. New York: World Bank, 2003. 